\title{
The Mechanisms of Inhibition of Advanced Glycation End Products Formation through Polyphenols in Hyperglycemic Condition
}

Authors

Affiliations
Shahpour Khangholi ${ }^{1}$, Fadzilah Adibah Abdul Majid ${ }^{1,2}$, Najat Jabbar Ahmed Berwary ${ }^{3}$, Farediah Ahmad ${ }^{4}$, Ramlan Bin Abd Aziz ${ }^{2}$

${ }^{1}$ Tissue Culture Engineering Laboratory, Universiti Teknologi Malaysia (UTM), Malaysia

2 Institute of Bio-products Development, Universiti Teknologi Malaysia (UTM), Malaysia

${ }^{3}$ College of Medicine, Hawler Medical University, Erbil, Iraq

${ }^{4}$ Department of Biochemistry, Faculty of Sciences, Universiti Teknologi Malaysia (UTM), Malaysia

Key words
AGEs
diabetic complications
polyphenols
antiglycation
hyperglycemia
antioxidant

received June 30,2014 revised June 25,2015 accepted August 20, 2015

Bibliography

DOI http://dx.doi.org/ 10.1055/s-0035-1558086 Published online November 9 , 2015

Planta Med 2016; 82: 32-45 (c) Georg Thieme Verlag KC Stuttgart · New York . ISSN 0032-0943

Correspondence Assoc. Professor Fadzilah Adibah Abdul Majid Head of Tissue Culture Engineering Laboratory Faculty of Chemical Engineering Universiti Teknologi Malaysia 81310 Johor Bahru, Johor Malaysia

Phone: + 60177853273

Fax: +6075535556

adibah@cheme.utm.my

\section{Abstract \\ $\nabla$}

Glycation, the non-enzymatic binding of glucose to free amino groups of an amino acid, yields irreversible heterogeneous compounds known as advanced glycation end products. Those products play a significant role in diabetic complications. In the present article we briefly discuss the contribution of advanced glycation end products to the pathogenesis of diabetic complications, such as atherosclerosis, diabetic retinopathy, nephropathy, neuropathy, and wound healing. Then we mention the various mechanisms by which polyphenols inhibit the formation of advanced glycation end products. Finally, recent supporting documents are presented to clarify the inhibitory effects of polyphenols on the formation of advanced glycation end products. Phytochemicals apply several antiglycation mechanisms, including glucose metabolism, amelioration of oxidative stress, scavenging of dicarbonyl species, and up/ down-regulation of gene expression. To utilize polyphenols in order to remedy diabetic complications, we must explore, examine and clarify

\section{Introduction}

\section{$\nabla$}

For thousands of years, plants have been used in traditional systems of medicine to remedy different kinds of disorders. Based on the records from $1981-2002$, around $40 \%$ of 877 new discovered chemical entities originated from nature [1]. Because of the biological advantages of nature originated drugs, scientists throughout the world have tried to explore and introduce new prototype drugs against diseases. Therefore a massive amount of information is needed to determine biological activity, action mechanisms, and fate of these new molecules in the body. the action mechanisms of the components of polyphenols.

\section{Abbreviations}

$\nabla$

ALEs: advanced lipoxidation end products

AGEs: advanced glycation end products

AR: $\quad$ aldose reductase

CML: carboxymethyllysine

EGCG: epigallocatechin-3-gallate

GLUT-4: glucose transporter type 4

GO: $\quad$ glyoxal

LDL: low density lipoprotein

MGO: methylglyoxal

MMPs: matrix metalloproteinases

NADPH: nicotinamide adenine dinucleotide phosphate hydrogen

NFkB: $\quad$ nuclear factor kappa B

PPAR: peroxisome proliferator-activated receptors

RAGE: receptor for AGEs

ROS: $\quad$ reactive oxygen species

TNF- $\alpha$ : $\quad$ tumor necrosis factor- $\alpha$

VCAM-1: vascular cell adhesion molecule 1

Diabetes is a chronic disease accompanied by hyperglycemia. Hyperglycemia accelerates the development of diabetic complications by several mechanisms, including increase in hexosamine pathway flux, increase in polyol pathway flux, activation of protein kinase $C$ isomers, and increase in AGEs formation. AGEs contribute to the pathogenesis of diabetes complications. Therefore inhibition of their formation is considered as a therapeutic approach for patients. Many studies have been conducted to examine the antiglycation activity of phytochemicals. It has been established that phytochemicals exert their effects via several mechanisms, which are mostly dependent on the molecular structure of the compounds. 


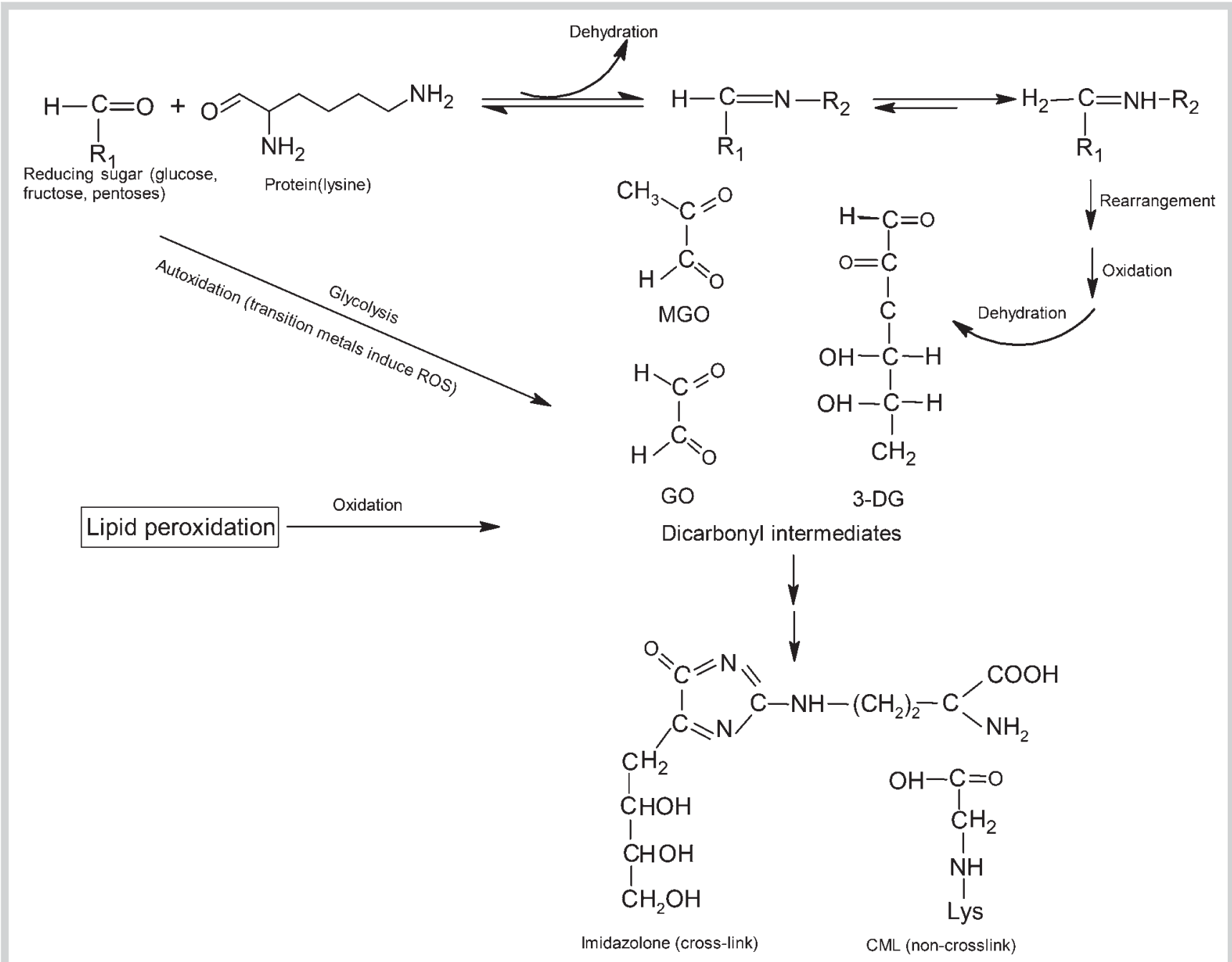

Fig. 1 Protein glycation pathways leading to AGEs formation.

\section{Advanced Glycation End Product Formation \\ $\nabla$}

Glycation (non-enzymatic glycosylation) is a chemical reaction in which the carbonyl group of a reducing sugar binds to an amino group of long-lived proteins, lipids, or peptides in the absence of enzymatic control to finally produce AGEs [2]. AGEs are heterogeneous compounds in the form of fluorescent cross-linking (e.g. pentosidine), non-fluorescent cross-linking (methylglyoxal-lysine dimers) and non-fluorescent non-cross-linking (CML and pyrraline) [3]. In the initial stage of glycation, carbonyl groups of reducing sugars such as glucose, fructose, or trioses bind to free amino groups of proteins in the absence of enzymatic control [4]. The yields of this reaction are known as Schiff base intermediates, which are unstable and reversible. In the second stage the compounds, after dehydration and rearrangement, convert to more stable Amadori products. Finally, after dehydration, oxidation and rearrangement, the Amadori products yield stable and irreversible compounds known as AGEs ( $\bullet$ Fig. $\mathbf{1})[5,6]$. Moreover, a variety of other pathways such as autoxidation of glucose, or ascorbate and lipid peroxidation, can also lead to AGE formation. The yields of these pathways usually are dicarbonyl intermediates, for example MGO, GO, 3-deoxyglucosone, glycolaldehyde, 1-deoxyglucosone [7] and free radicals [8]. Reaction of glyoxal or methylglyoxal with free lysine groups of proteins gives rise to the formation of AGEs such as CML, carboxyethyllysine or methylglyoxal lysine dimer [9].

\section{Role of Advanced Glycation End Products in the Pathogenesis of Diabetic Complications \\ $\nabla$}

AGEs contribute to the development and progression of diabetes complications, including micro- or macroangiopathy. AGEs exert their damaging effects on cell functions through several mechanisms such as production of free radicals, fragmentation of protein or lipid, altering enzyme activity, modifying immunogenicity, oxidation of nucleic acids or lipids, carbonyl stress or interaction with AGEs receptors on the cell surface [10].

The AGEs are capable of forming an AGE-receptor complex by binding to specific or non-specific receptors such as AGE-R1 (P60/OST-48 protein), AGE-R2 (80 K-H phosphoprotein), AGE-R3 (galectin), and AGE-RAGE [11-13]. Among different receptors RAGE as a multi-ligand receptor of the immunoglobulin superfamily, plays a distinguished role in the onset of AGEs induced metabolic disorders ( 0 Fig. 2). AGE-RAGE complex not only alters the structures and functions of proteins but also activates some 


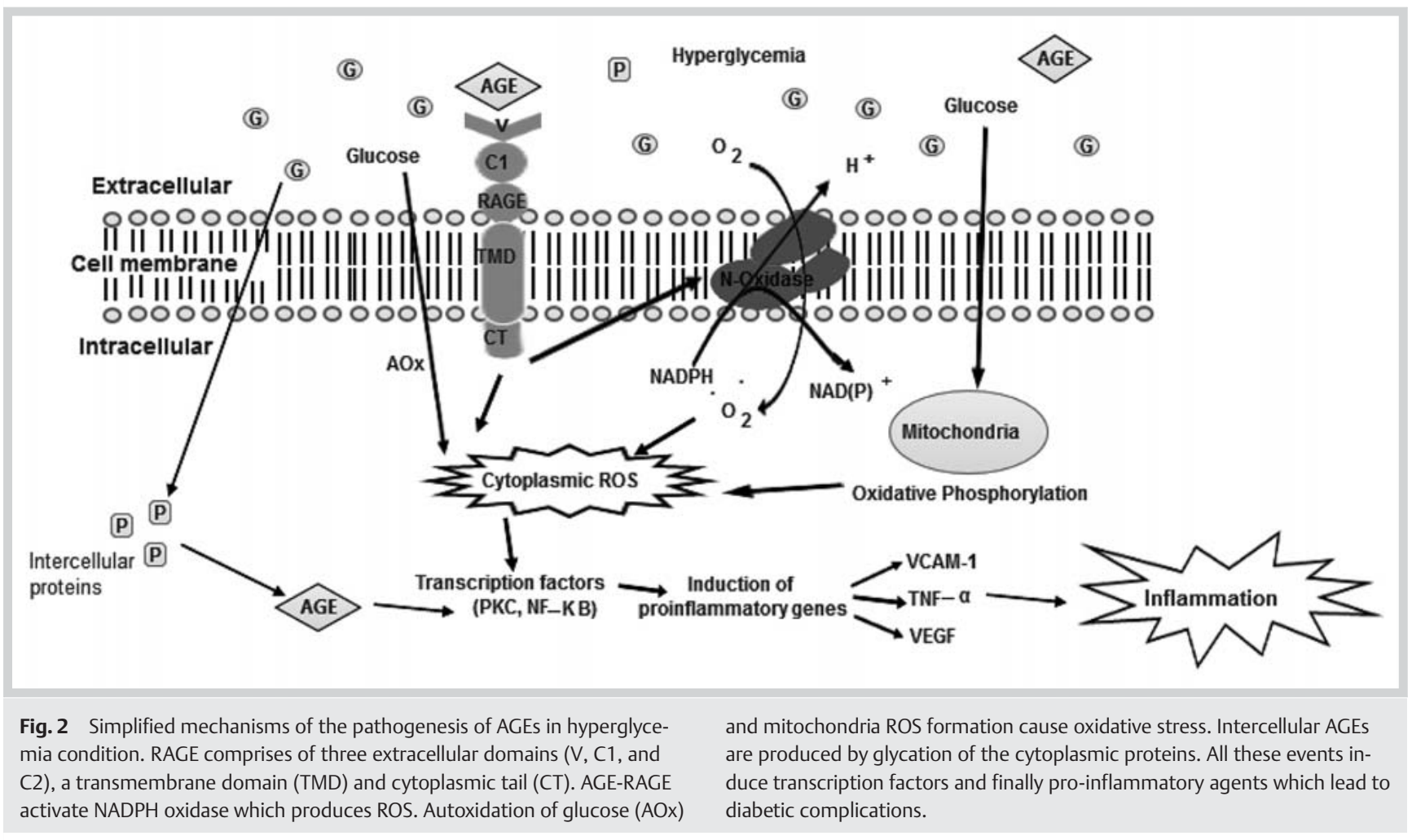

intercellular signaling pathways such as those of protein kinase $C$ or transcription factor NFkB, triggers NADPH-oxidase, chemo-attractive and proinflammatory gene expression [14], VCAM-1, or intercellular adhesion molecules-1 (ICAM-1) [15].

\section{Atherosclerosis}

Diabetes is recognized as a noticeable risk factor for the progress of atherosclerosis, which is a major contributor to morbidity and mortality in diabetic patients. Hyperglycemia result in higher accumulated amounts of AGEs in the blood vessels that induces proliferation of smooth muscle cell, thickening of intima (due to plaque formation and its sedimentation), and rigidity and stiffness of the vessels $[16,17]$. Foam cell formation is considered as a risk factor for atherosclerosis. AGEs contribute to foam cell formation through several mechanisms such as enhancement of lipid and protein glycosylation [18], lipid uptake, increasing production of ALEs, or oxidation of LDL. LDL is absorbed by blood monocytes $[18,19]$. In blood circulation, oxidized LDL are not removed through normal pathways and thus are absorbed and deposited in vascular walls by monocytes to form foam cells (ه Fig. 3) [19]. It should be noted that AGEs stimulate the differentiation of monocytes to macrophages (a kind of vascular cell) as well [20]. In an experiment AGEs altered the cholesterol transport system by decreasing special proteins for cholesterol efflux known as ABCA-1 and ABCG-1, which resulted in impaired cholesterol emission through bile and feces and caused cholesterol accumulation in the body [21]. Another effect of AGEs on the induction of atherosclerosis is related to interaction of AGEs with RAGE on the cell surface. AGE-RAGE complex induces atherosclerosis through enhancement of the expression of VCAM-1 on endothelial cells [22]. VCAM-1 facilitates the adhesion of mononuclear proinflammatory cells, and the activation of NADPH oxidase, which finally accelerates migration of lymphocytes from stimulated cells [23]. Furthermore VCAM-1 promotes the adhe-

sion of monocyte to endothelial cells. In the next stage, monocytes differentiate into intimal macrophages, which transform into the foam cells by lipid uptake [24].

\section{Diabetic retinopathy}

Retinopathy is the most common cause of blindness in diabetic patients. In diabetic retinopathy, accumulation of AGEs promotes disorders such as thickening of the capillary basement membrane, enhancing of permeability of capillaries and vascular leakage, apoptosis of pericytes [25], prevention of DNA synthesis of retinal pericytes, and finally increasing of endothelial cell death [26]. AGEs receptors are located on the surface of pericytes. Hyperglycemia stimulates an excessive expression of RAGE on pericytes and endothelial cells which results in a deterioration of pericytes. Loss of pericytes leads to vascular damage and clinical expression of retinopathy $[27,28]$. Moreover, a high level of AGEs in retinal cells induces expression of vascular endothelial growth factor which causes destruction of the blood-retinal barrier and microvascular hyper-permeability, which finally leads to blindness or poorness of vision [29].

\section{Diabetic nephropathy}

Diabetic nephropathy is associated with basal membrane thickening, decreased filtration and mesangium expansions which, in developed conditions result in final renal disease [30]. Expansion of the mesangial layer due to sedimentation of protein in glomerular mesangial space, in the company of partial proliferation [31] plays a significant role in reduction of filtration via decreasing the surface area due to pressing of capillaries [32], or occlusion of capillaries [23]. The elevated level of AGEs in serum also enhances the level of transforming growth factor-b, which in turn stimulates the formation of collagen matrix, or at least in part, basal membrane thickening [30]. Increment of growth factors promotes vascular permeability and reduces barrier activities [33], 


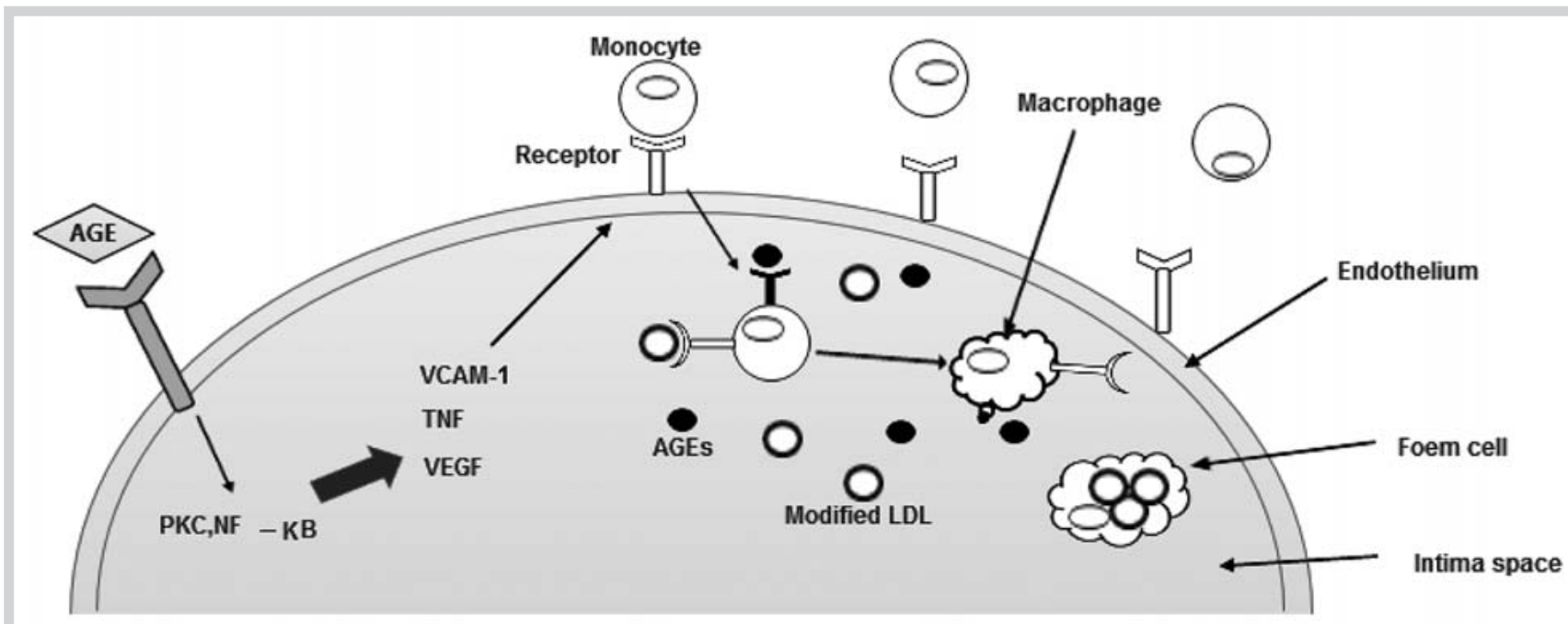

Fig. 3 Foem cell formation in diabetic vascular. AGEs causes proinflammatory signaling pathways, which stimulate the transformation of monocytes to macrophages.

which may result in a kidney malfunction. Moreover AGEs accumulation on collagen in the basal membrane along with capability of trapping plasma membrane can also cause thickening of basal membrane and reduce filtration [30]. AGEs stimulates an extreme RAGE expression, which encourages cell inflammation signaling pathways such as mitogen-activated protein kinases and NFkB [34]. AGE-RAGE complex encourages the generation of cytokines and growth factors as well. Increment of growth factors increases vascular permeability and reduction of barrier activities [33].

\section{Diabetic neuropathy}

In severe diabetic neuropathy, the nerve system fails to perform its function properly due to a demyelination of the nerves or a axonal deterioration of the peripheral neurons. Nerve demyelination occurs through a mechanism in which macrophages uptake glycated myelin and then secrete proteases [30]. Likewise, AGEs on the myelin react with plasma protein such as IgM and IgG to stimulate the segmental demyelination of peripheral neurons [35]. The complex of AGE-RAGE located on peripheral nerves or dorsal root ganglion induces ROS formation and several intercellular signaling pathways [36]. ROS promotes both AGE formation and AGEs quenching by nitric oxide. Consequently the nitric oxide level in the cell is decreased and results in nerve ischemia (lack of oxygen to the nerve) as a cause of nerve dysfunction [37].

\section{Diabetic wound healing}

In diabetic patients, amputation is a serious concern as a consequence of impaired wound healing. Wound healing comprises some consecutive phases including inflammation, proliferation and remodeling of the cells, and angiogenesis (formation of collagen and extracellular matrix in the wounded area) [38]. However the healing process fails to be completed in diabetic conditions. Some proinflammatory compounds such as TNF- $\alpha$, interleukin6; and MMPs delay the wound closure by a breakdown of collagen [39]. It has been reported that AGE-RAGE complex increased TNF- $\alpha$ and MMPs and retarded the wound healing process in diabetic mice. In contrast, the inhibition of AGE-RAGE formation by blocking RAGE resulted in faster wound repair and regeneration [40]. Similarly, the presence of AGE-RAGE complex on fibroblasts reduced the formation of collagen as a necessary compound for wound repairing [41]. The negative effect of AGE-RAGE on wound healing has been stated in animal studies using application of exogenous AGEs [16,42].

\section{Structure-Activity Relationship with Antiglycation Activity of Phenolic Compounds \\ $\nabla$}

A large body of in vitro and in vivo experiments have shown the potential of dietary bioactive compounds against AGEs formation and accumulation ( Table 1 ). Plants are the main source of natural compounds for medicinal use. Polyphenolic compounds as the major and ubiquitous phytochemicals comprise more than 8000 components [43]. These phytochemicals exhibit various biological activities important in plant life, such as defense mechanisms against insects, herbivores, disease or modulator of gene expression (transcription factors, redox-sensitive transcription factors, redox signaling, and signal transduction pathways), and as antioxidants under stress conditions.

Fortunately phytochemicals play a multifunctional role in human health as well ( Fig. 4). Phytochemicals attenuate free radicalinduced chronic diseases (e.g. diabetes complications), infertility, or neurodegenerative diseases by scavenging free radicals like ROS or reactive carbonyl species [44].

Multidisciplinary studies have demonstrated that the composition of a polyphenol has an outstanding relationship to its antioxidant properties. On the other hand, the antioxidant activity of a natural compound shows strong linking with its molecular structures [45]. Therefore, it is an important matter to assess the antioxidant activity of a polyphenolic compound not only quantity but also by quality (which is decided by chemical structure). The antioxidant ability of a compound is dependent on its capacity to donate electron or hydrogen atoms to free radical molecules. Structurally polyphenolic compounds consist of one or more aromatic rings, with one or more hydroxyl groups $(\mathrm{C}-\mathrm{OH})$ with other substituents ( Fig. 5) [43]. 
Table 1 Therapeutic mechanisms of plants in relation to AGEs formation.

\begin{tabular}{|c|c|c|c|}
\hline Plant & Active compound(s) & Therapeutic mechanism(s) & Ref. \\
\hline Achyrocline satureoides (Macela) & Achyrofuran & $\begin{array}{l}\text { Inhibited AGE-precursor production lowered } \\
\text { blood glucose levels }\end{array}$ & [78] \\
\hline Allium sativum (Garlic) & $\begin{array}{l}\text { S-allylcysteine, S-ethylcysteine, } \mathrm{N} \text {-acetyl- } \\
\text { cysteine }\end{array}$ & Decreasing LDL glycation & [50] \\
\hline Alpinia zerumbet (Shell ginger) & $\begin{array}{l}\text { 5,6-dehydrokawain (DK), dihydro-5,6-dehy- } \\
\text { drokawain (DDK), Labdadiene }\end{array}$ & $\begin{array}{l}\text { Inhibition of Amadori products formation, } \alpha \text { - } \\
\text { dicarbonyl compounds and glycation of amino } \\
\text { group }\end{array}$ & [51] \\
\hline Astragalus membranaceus (Milk Vetch) & Astragaloside IV (AGS-IV) & $\begin{array}{l}\text { Lowering glucose level and aldose reductase } \\
\text { pathway increasing plasma insulin levels and } \\
\text { glutathione peroxidase activity }\end{array}$ & [67] \\
\hline Camellia sinesis (Green and Black tea) & Epicatechins, theaflavins, EGCG & Trapping of $\alpha$-dicarbonyl compounds & {$[54,97]$} \\
\hline $\begin{array}{l}\text { Chrysanthemum morifolium and C. indicum } \\
\text { (Chrysanthemum) }\end{array}$ & $\begin{array}{l}\text { Chlorogenic acid, flavonoid glucoside, } \\
\text { apigenin, caffeic acid, luteolin, kaempferol }\end{array}$ & Free radical and metal scavenging & [49] \\
\hline Cinnamomum zeylacnicum (Cinnamon) & $\begin{array}{l}\text { Cinnamtannin B1, catechin, epicatechin, } \\
\text { procyanidin B2 }\end{array}$ & Mimicking insulin activity & [45] \\
\hline Curcuma longa (Turmeric) & Curcumin & $\begin{array}{l}\text { Preventing free radicals and glycosylated hae- } \\
\text { moglobin }(\mathrm{HbA}) \text { formation, protecting non-en- } \\
\text { zymatic antioxidants pools, preventing of lipid } \\
\text { peroxidation, lowering blood glucose level }\end{array}$ & $\begin{array}{l}{[59,61,} \\
62,66]\end{array}$ \\
\hline Cyperus rotundus (Nut sedge) & Gallic acid, p-coumaric acid, epicatechin & $\begin{array}{l}\text { Reduction of protein carbonyl and thiol } \\
\text { oxidation }\end{array}$ & [5] \\
\hline Garcinia indica (Kokum fruit) & Garcinol & Metal ion chelation & [88] \\
\hline Glycine max (Soybean) & $\begin{array}{l}\text { Epigallocatechin, epicatechin gallate, } \\
\text { isoflavones }\end{array}$ & $\begin{array}{l}\text { Inhibitory effect on } \alpha \text {-amylase or } \alpha \text {-glucosidase } \\
\text { activity, interruption of GLUT4 }\end{array}$ & [59] \\
\hline Glycyrrhiza glabra (Licorice) & Tannic acid, glycyrrhizin & $\begin{array}{l}\text { Inhibitory effect on } \alpha \text {-amylase or } \alpha \text {-glucosidase } \\
\text { activity, interruption of GLUT4 }\end{array}$ & [59] \\
\hline $\begin{array}{l}\text { Gymnema sylvestre (Australian cowplant or } \\
\text { Gurmari) }\end{array}$ & $\begin{array}{l}\text { Gymnemic acid, (+) quercitol, lupeol, (-) amyr- } \\
\text { in, stigma sterol, kaempferol, D-glucopyrano- } \\
\text { syl, alpha-L-rhamnopyranosyl }\end{array}$ & $\begin{array}{l}\text { Preventing lipid peroxidation, lowering blood } \\
\text { glucose level }\end{array}$ & {$[59,61]$} \\
\hline Ilex paraguariensis (Mate or Yerba mate) & Caffeic and chlorogenic acid & Inhibition of AGE-precursor formation & {$[78,85]$} \\
\hline $\begin{array}{l}\text { Malus domestica (Apple), Ananas comosus } \\
\text { (Pineapple), Coffea sp. (Coffee), Helianthus } \\
\text { annuus (Sunflower) }\end{array}$ & Chlorogenic acids & $\begin{array}{l}\text { Metal ions chelation or modulation of anti- } \\
\text { oxidant enzymes gene expression }\end{array}$ & [85] \\
\hline Momordica charantia (Bitter melon) & Not reported in the referenc & $\begin{array}{l}\text { Improve oxidative stress through lowering tri- } \\
\text { glyceride, cholesterol or plasma glucose levels, } \\
\text { stimulation of insulin secretion }\end{array}$ & [84] \\
\hline Nigella sativa (Black seed) & Quinones, Thymoquinone & $\begin{array}{l}\text { Decreasing of MGO-mediated glycation, } \\
\text { scavenging reactive oxygen species, anti- } \\
\text { oxidant activity }\end{array}$ & [79] \\
\hline $\begin{array}{l}\text { Phyllanthus niruni (Chanca Piedra or Child } \\
\text { Pick-a-back) }\end{array}$ & Ellagic acid & Inhibitory activity against AR in rat lens & [73] \\
\hline Psidium guajava (Guava) & Gallic acid, catechin, quercetin & $\begin{array}{l}\text { Chelating activity, scavenging of } \alpha \text {-dicarbonyl } \\
\text { compounds }\end{array}$ & [89] \\
\hline Pterocarpus marsupium (Indian Kino Tree) & Pterosupin & $\begin{array}{l}\text { Decreasing lipid peroxidation and supporting } \\
\text { antioxidant defense system }\end{array}$ & [59] \\
\hline Pueraria lobata (Kudzu) & Puerarin PG-3, and puerol B & $\begin{array}{l}\text { Decreasing AGE-induced inflammation by } \\
\text { inducing of the } \mathrm{HO}-1\end{array}$ & $\begin{array}{l}{[83,} \\
103]\end{array}$ \\
\hline Punica granatum (Pomegranate) & $\begin{array}{l}\text { Punicalagin, ellagic acid, anthocyanins, } \\
\text { oleanolic acid, ursolic acid, gallic acid, oleanolic } \\
\text { acid ursolic acid }\end{array}$ & $\begin{array}{l}\text { Inhibition of LDL oxidation, reduction of NFKB } \\
\text { activity, decreasing fat intake and increasing fat } \\
\text { excretion, cardiac PPAR-gamma mRNA expres- } \\
\text { sion and sensitivity to insulin receptor }\end{array}$ & $\begin{array}{l}{[77,92,} \\
105]\end{array}$ \\
\hline Solanum lycopersicum (Tomato) & Quercetin and rutin & $\begin{array}{l}\text { Trapping of } \alpha \text {-dicarbonyl compounds, } \\
\text { inhibition of glucose autoxidation }\end{array}$ & $\begin{array}{l}{[70,} \\
100]\end{array}$ \\
\hline Stelechocarpus cauliflorus (Kepel) & Flavonoids (Astilbi, engeletin) & $\begin{array}{l}\text { AR inhibitory effect through deactivation of } \\
\text { enzyme-substrate complex }\end{array}$ & [72] \\
\hline Trigonella foenum-graeceum (Fenugreek) & Trigonilline & $\begin{array}{l}\text { Decreasing cholesterol LDL and lipid peroxida- } \\
\text { tion, supporting antioxidant defense system, } \\
\text { lowering blood glucose }\end{array}$ & {$[59,94]$} \\
\hline Vaccinium angustifolium (Lowbush blueberry) & Anthocyanins, Antocyanidins & $\begin{array}{l}\text { Up-regulation of expression of PPAR gamma or } \\
\text { involving genes in glucose or lipid metabolisms }\end{array}$ & $\begin{array}{l}\text { [59] } \\
\text { cont. }\end{array}$ \\
\hline
\end{tabular}

Investigations on the structure-antioxidant activity of flavonoids, as ubiquitous polyphenols in plants, have verified three key positions on the structure of polyphenolic compounds which are not only important for antioxidant activities but also for antiglyca- tion properties. These positions are located at ortho-3',4'-dihydroxy in the B ring, the 2,3-double bond in conjunction with the 4-oxo group in the $\mathrm{C}$ ring, and the presence of 3-OH group in $\mathrm{C}$ ring and 5-OH group in the A ring [46]. In this regard, the flavo- 
Table 1 Continued

\begin{tabular}{|lll|}
\hline Plant & Active compound(s) & Therapeutic mechanism(s) \\
\hline $\begin{array}{l}\text { Vaccinium spp. (Blueberries, Cranberries) } \\
\text { Rubus spp. (Blackberries) } \\
\text { Fragaria } \times \text { ananassa (strawberries) }\end{array}$ & Procyanidins, anthocyanin & $\begin{array}{l}\text { Inhibiting of Amadori products formation, } \\
\text { scavenging of } \alpha \text {-dicarbonyl compounds }\end{array}$ \\
\hline $\begin{array}{l}\text { Vigna radiata (Mung bean) } \\
\text { Vitis vinifera (Grape) }\end{array}$ & Phenolic compounds vitexin, isovitexin & $\begin{array}{l}\text { MGO inhibitory activity by free radical } \\
\text { scavenging capacity }\end{array}$ \\
\hline
\end{tabular}

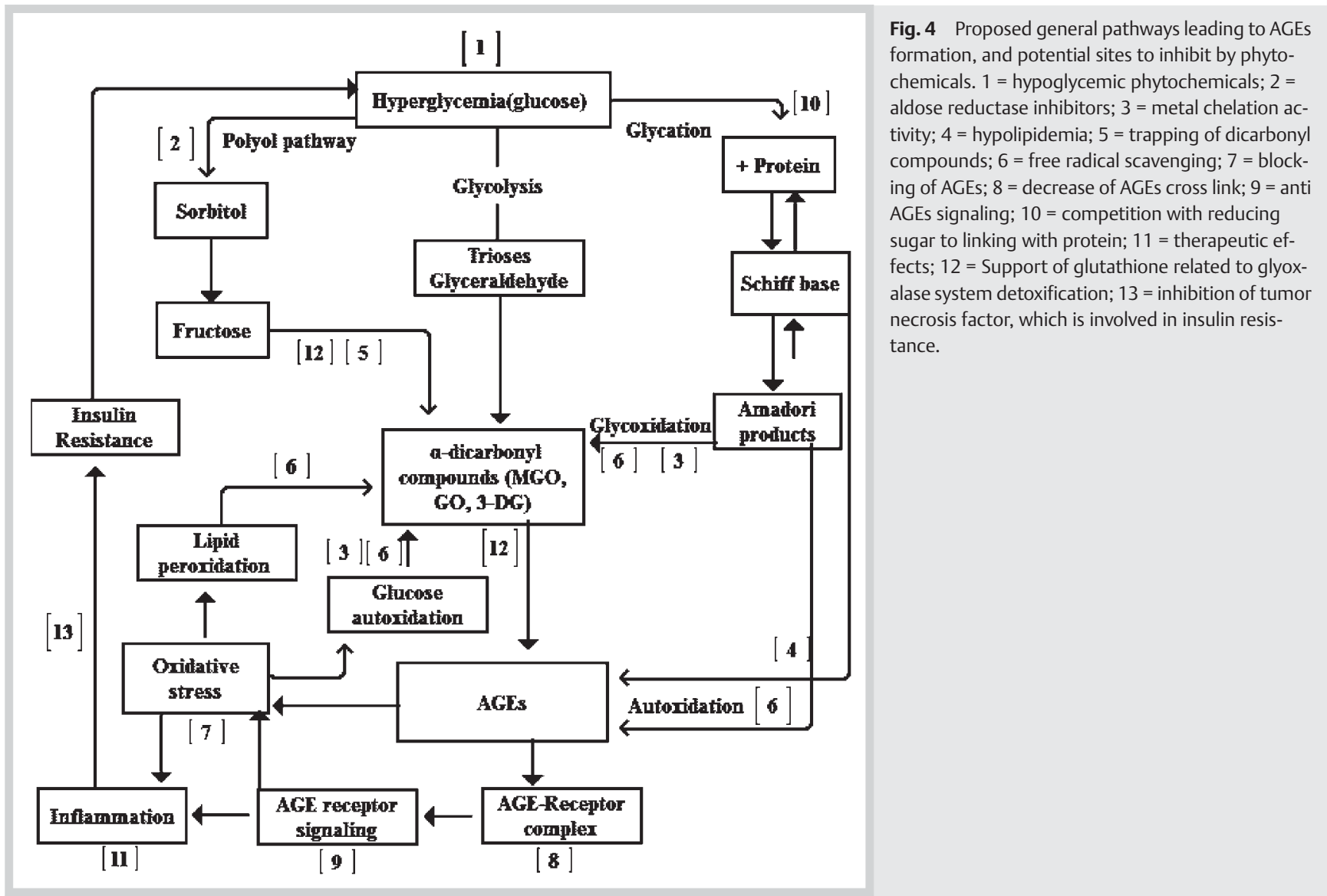

noids with an $\mathrm{OH}$ group at $\mathrm{C}-3^{\prime}$ are stronger AGEs inhibitors than those with $\mathrm{OH}$ at $\mathrm{C}-3$. Any hydroxyl group on positions 3', 4', 5, and 7 increases the AGEs inhibitory ability of the compound ( Fig. 5) [35]. It should be noted that other polyphenolic compounds apart from flavonoids have shown antiglycation activity as well. For example, resveratrol (3,4,5-trihydroxystilbene) a phytoestrogen from grapes, significantly inhibited AGEs-induced proliferation, collagen synthesis, and decreased oxidative stress in rats [47].

Plant species, cultivars of a specific species or even different organs of a same plants may exhibit different AGEs inhibitory activities according to the chemical structure of their components, which is controlled by genetic factors and growing conditions. The levels and chemical compositions of polyphenols may fluctuate significantly during the growing season, which consequently alters antiglycation and antioxidant properties of the plant. There is evidence that extract of the antidiabetic plant commonly called lowbush blueberry [Vaccinium angustifolium Ait. (Ericaceae)], had the highest antiglycation activity, if the plants were harvested in late summer. Alteration in polyphenol levels during the harvesting period has been shown for some compounds, such as such as chlorogenic acid, rutin, quercetin3-arabinoside, (+)-catechin, and (-)-epicatechin [48].

In a comparative antiglycation study among some bean species, alcoholic extract of mung bean, Vigna radiate (L.) R.Wilczek (Fabaceae), displayed the highest inhibitory activity on AGEs formation due to its higher amount of phenolic compounds known as vitexin and isovitexin [45]. Vitexin contains a 4'- hydroxyl group in the B ring of its structure [43]. Tsuji-Natio et al. reported that Chrysanthemum morifolium Ramat. (Asteraceae) prevented the formation of fluorescent AGEs more effectively than Chrysanthemum indicum $\mathrm{L}$. due to a higher content of flavonoids and other active components in its extract [49]. It is evident that different organs of the same plant produce different secondary metabolites. There is growing evidence that a remarkable alteration of 
<smiles>O=C(O)c1cc(O)c(O)c([18OH])c1</smiles>

Gallic acid

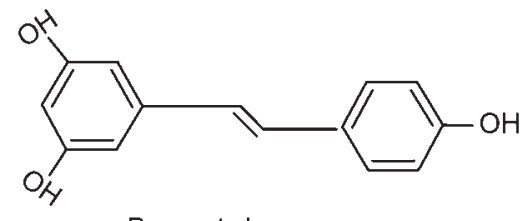

Resveratrol

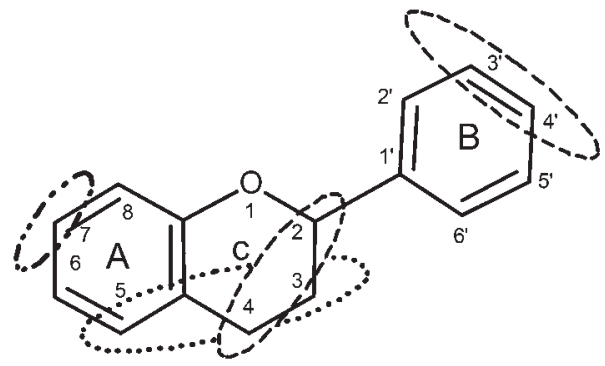

Basic structure of flavonoids

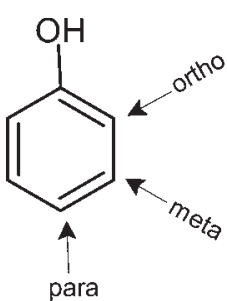

Phenol structure
Fig. 5 Structure of some simple phenolic compounds. All polyphenols contain an aromatic ring with a hydroxyl group (or different functional groups). Important positions on the flavonoids molecule, which are determinant in biological role and activity of flavonoids. the profile of polyphenols from the same plant organ occurs when it is harvested in different time periods or regions [50]. In an investigation, extracts of various organs of Alpinia zerumbet B.L.Burtt \& R.M.Sm. (Zingiberaceae) displayed different antiglycation activities. In that experiment, extracts from flowers and leaves showed the highest and the least inhibitory activity against formation of $\alpha$-dicarbonyl compounds, respectively [51]. Ferchichi et al. showed antiglycation activity of alcoholic extracts of different organs of Calophyllaceae and Clusiaceae species. The results showed significant differences between various parts of the plants [52]. However, in some cases, contradictory results have been reported. For example, Lunceford and Gugliucci reported no dicarbonyl trapping activity for green tea in vitro [53], while Sang et al. expressed that green tea polyphenols such as EGCG prevent AGEs formation by trapping of MGO or GO [54]. Such contradictory results may occur due to the application of different concentrations, different methods of measurement or extract preparation, and to the accuracy of the applied equipment.

\section{Antiglycation Mechanisms of Polyphenols \\ $\nabla$}

\section{Glucose metabolism control}

In hyperglycemic conditions, lowering of blood glucose level is considered as a significant approach to limit AGEs formation and accumulation. Insulin, as a key gluco-regulatory hormone, simultaneously regulates cell glucose uptake, increases glycogenesis, and inhibits glucagon secretion ( Fig. 6). Some phytochemicals decrease blood glucose level by mimicking insulin activity. Obanda et al. reported that bioactive compounds of Artemisia dracunculus L. (Asteraceae) amplified cell insulin sensitivity by restoration of protein kinase B phosphorylation. Moreover, it reduced signaling pathway mediated by sphingolipid ceramides, which may cause cellular insulin resistance [55]. Cinnamtannin B1 from Cinnamomum zeylanicum Blume (Lauraceae) helped glucose uptake by stimulating the phosphorylation of insulin receptors on 3T3-L1 cell line [56]. Cinnamon also contains catechin, epicatechin, and procyanidin B2, which all possess antiglycation activity [45]. According to Zhao et al. berberine isolated from some plants improved diabetic complications in diabetic rats through attenuation of insulin resistance and activation of insulin-like growth factor-binding protein signaling pathways [57]. In an animal experiment Peng et al. showed that extract of Hibiscus sabdariffa $\mathrm{L}$. (Malvceae) lowered the blood glucose level and improved insulin resistance [58].

Since pancreatic $\beta$-cells secrete insulin, any damage to these cells causes insufficient insulin secretion, and therefore accumulation of glucose in the blood stream. Some plants such as Pterocarpus marsupium Roxb. (Fabaceae), Gymnema sylvestre (Retz.) Schult. (Apocynaceae), Ziziphus jujube Miller (Rhamnaceae), or Trigonella foenum-graecum L. (Fabaceae) showed protective effects on pancreatic $\beta$-cells by decreasing lipid peroxidation, amplifying insulin secretion or supporting antioxidant defense system (increasing of glutathione and beta carotene levels of plasma in diabetic rats) [59].

Enzymatic breakdown of polysaccharides (such as starches) to monosaccharide (glucose) by $\alpha$-amylase or $\alpha$-glucosidase in- 


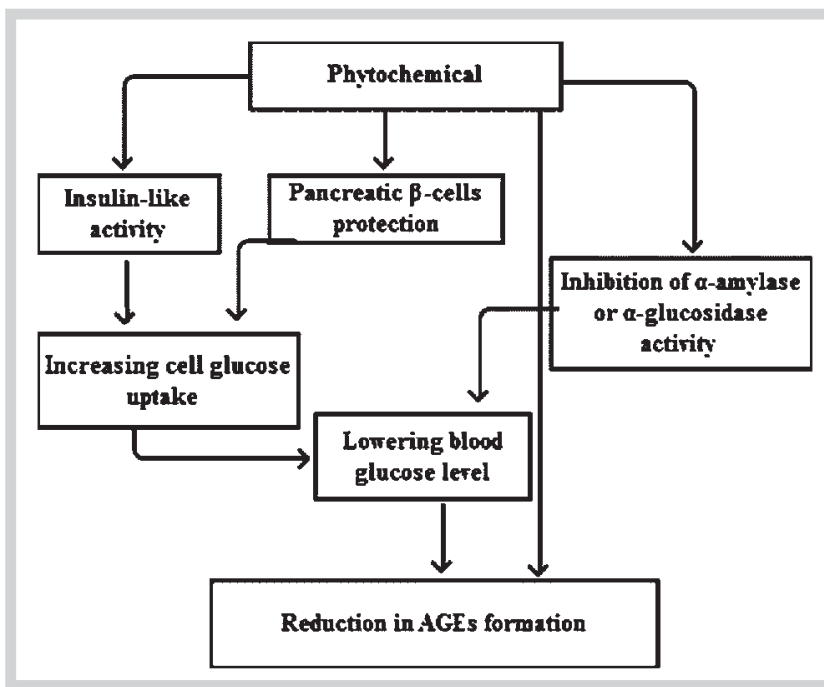

Fig. 6 The role of phytochemicals in inhibition of AGEs formation by lowering glucose levels.

creases the glucose level in the blood stream, resulting in an upregulation of glucose metabolism and finally in an increase of AGEs formation. Phytochemicals such as epigallocatechin, epicatechin gallate, isoflavones (isolated from soybeans), tannic acid and glycyrrhizin (isolated from licorice root), chlorogenic acid, and saponins do not only decrease the activity of $\alpha$-amylase or $\alpha$-glucosidase, but also reduce the active transport of glucose through the intestines [59]. Proanthocyanidins are the major polyphenolic components of the roots and stems of Polygonum multiflorum Thunb (Polygonaceae). They possess hypoglycemic properties to reduce blood glucose level by inhibition of $\alpha$-amylase and $\alpha$-glucosidase activities [60]. In vitro and in vivo studies demonstrated a lowering of blood glucose level by curcumin [active compound of Curcuma longa L. (Zingiberaceae)] or extracts of G. sylvestre [61,62]. In an experiment on diabetic mice curcumin simultaneously reduced glucose level and raised up the plasma insulin level. The mechanism by which curcumin lowered the glucose level was increasing the activity of hepatic glucokinase to facilitate converting extra glucose to glycogen. Moreover, free fatty acid, cholesterol, and triglyceride concentrations dropped in the curcumin-supplemented diabetic mice [63]. Furthermore Tang and Chen reported that curcumin inhibited the membrane translocation of GLUT4 and induced glucose conversion to glucose-6-phosphate resulting in reduced intercellular glucose level [64].

Predominant structure of natural flavonoids in plants is flavonoid glycosides. Despite the fact that glycosylation of flavonoids decreases the potential of their $\alpha$-amylase inhibitory activity, they are still able to deactivate $\alpha$-amylase by formation of complex. Investigations have shown that monoglycoside flavonoids (i.e. quercitrin and hyperin) have stronger $\alpha$-amylase inhibitory effects than polyglycoside flavonoids (i.e. rutin). This can be explained by the alteration of molecular size and polarity after glycosylation. During glycosylation, hydroxyl group(s) is (are) replaced by glycoside(s) resulting in weakening the bond between amylase and flavonoids. Flavonoids with anti- $\alpha$-amylase activity have been extensively investigated [65].

Some polyphenols have multifunctional properties to control AGEs formation. For example, in vivo studies showed several ben- eficial effects of turmeric (C. longa) on glucose metabolism, including preventing the formation of free radicals and glycosylated hemoglobin (HbA1c), increasing total hemoglobin [62], protecting non-enzymatic antioxidants pools, breaking of crosslink in collagen, preventing lipid peroxidation, and AGE-collagen accumulations [66]. In another animal study, root extracts of Astragalus membranaceus (Fisch.) Bunge (Fabaceae) lowered AGEs and $\mathrm{HbA} 1 \mathrm{c}$ formation by increasing plasma insulin levels and decreasing aldose reductase pathway along with enhancing glutathione peroxidase activity [67].

\section{Inhibition of aldose reductase activity}

$\mathrm{AR}$, the first enzyme in the polyol pathway, reduces glucose to sorbitol with consumption of NADPH. Then, sorbitol is oxidized to fructose by sorbitol dehydrogenase. Fructose is much stronger than glucose to produce $\alpha$-dicarbonyl compounds or AGEs adducts ( Fig. 7). In contrast to normal conditions, in hyperglycemia the mechanism of the polyol pathway exhibits a noticeable role in lowering glucose levels in the blood stream.

The polyol pathway contributes to the aging process, at least in part, by increasing MGO formation which later conjugates with the proteins and elevates AGEs formation. Hallam et al. [68] reported that in hyperglycemic rats AR inhibitors significantly reduced MGO formation. Therefore, inhibition of the polyol pathway can be considered as a potential approach to reduce AGEs formation. Butein and sulfuretin, polyphenolic compounds from Rhus verniciflua Stokes (Anacardiaceae), showed potent anti-AR and antiglycation activities. In a study conducted by Lee et al. butein showed AR inhibitory activity more than twice stronger than epalrestat (synthetic AR inhibitor). In that experiment AGEs inhibitory activity of sulfuretin was reported 10 times greater than aminoguanidine (synthetic AGEs inhibitor) [69]. Generally, hydroxylation of flavonoids make them more capable to inhibit AGEs formation. As a conclusion, the strong antiglycation activity of butein is caused by its molecular structure, which is tetrahydroxylated with -OH groups on 3-, 4-, 2' and 4' positions [69]. Metabolites of rutin, a flavonoid compound, especially those containing vicinyl dihydroxyl groups in the B-ring prevented AR activity. In contrast, the flavonoids without vicinyl dihydroxyl groups did not show antiglycation or anti-AR activity even at high concentrations [70]. Among some flavones isolated from Phyllostachys nigra (Lodd. ex Lindl.) Munro (Poaceae) the strongest anti-AR activity was achieved by luteolin 6-C-(6"-O-transcaffeoylglucoside), with tetrahydroxylated positions of 3'-, 4'-, 5, and 7- in the molecular structure [71]. Astilbin and engeletin, flavonoids isolated from Stelechocarpus cauliflorus (Scheff.) R.E. Fr. (Annonaceae), have demonstrated AR inhibitory activity in porcine lens. They prevented sorbitol formation through inactivation of AR-substrate complex by formation of enzyme-substrate-inhibitor complex [72]. In an experiment among three phenolic compounds isolated from Phyllanthus niruni L. (Phyllanthaceae), including brevifolin carboxylic acid, ethyl brevifolin carboxylate, and ellagic acid, the latter one demonstrated the most potent AR inhibitory activity [73].

However, the advantages or disadvantages of AL inhibitors are controversial issues in hyperglycemic situations. For example, in contrast with some evidence that AR contributes to AGEs formation through fructose production, some authors claimed that AR catalyzes a wide range of AGEs and ALEs precursors, including $\alpha$ dicarbonyls, hydrophobic aldehydes, and phospholipids aldehydes in long term and in severe hyperglycemia condition. According to Baba et al. streptozotocin AR-null mice showed more 


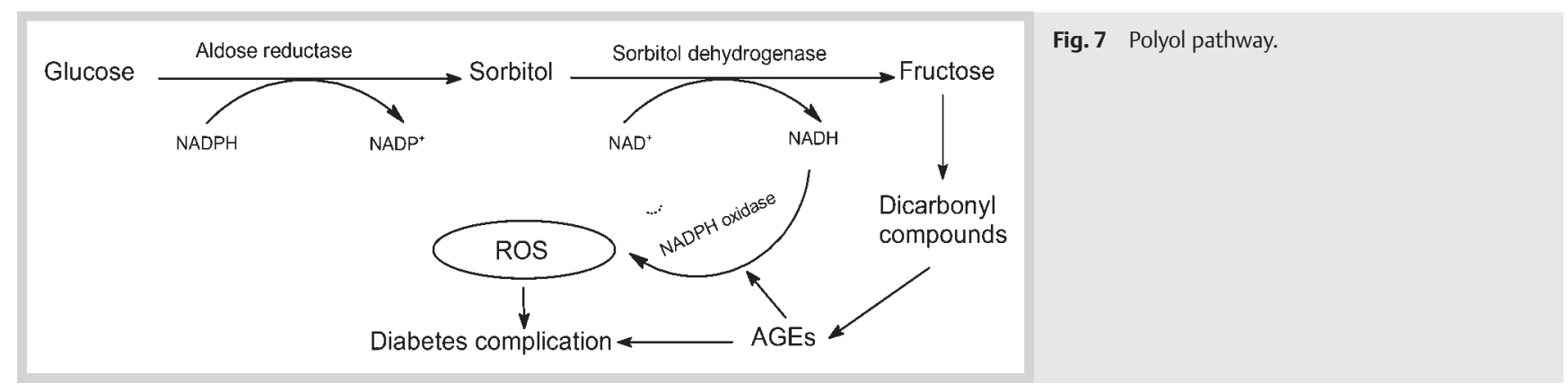

AGEs accumulation than streptozotocin wild type mice so as they reasonably concluded that in long term hyperglycemic condition, AR takes part in preventing the formation of AGEs [74].

\section{Antioxidant activity \\ $\nabla$}

\section{Free radical scavenging}

In oxidative stress condition, cascade of ROS formation causes an imbalance in the amounts of oxidants and antioxidants inside the cells. This condition encourages of glucose autoxidation and lipid peroxidation which finally lead to AGEs and ALEs formation, respectively. Lipid peroxidation yields malondialdehyde, which ultimately produces ALEs compounds that are functionally similar to AGEs [75]. Oxidation of polyunsaturated fatty acids (lipoxidation) may also lead to glyoxal or methylglyoxal formation. Reaction of glyoxal with free amino group of lysine or arginine produces CML or hydroimidazolones, respectively [9]. On the other hand ROS originated from mitochondria inhibitory activity of glyceraldehyde-3-phosphate dehydrogenase, which results in the production of glyceraldehyde-3-phophate, that is not only precursor of methylglyoxal (intermediate compound for AGEs) but also a source of superoxide formation [75]. In the next stage, hydrogen peroxide $\left(\mathrm{H}_{2} \mathrm{O}_{2}\right)$ is generated by superoxide under nonenzymatic dismutation reaction. The $\mathrm{H}_{2} \mathrm{O}_{2}$ reacts with $\mathrm{Fe}^{2+}$ through Fenton reactions to provide a hydroxyl group. Finally hydroxyl group cleavages a $\mathrm{C}-\mathrm{C}$ bound in Amadori product to make CML as an AGE adduct [76]. From this brief explanation, it seems that phenolic compounds with their antioxidant properties are capable to suppress AGE formation by trapping free radicals. According to Celik et al., pomegranate [Punica granatum L. (Lythraceae)] flower extract, or fruit juice improve oxidative stress by preventing lipid peroxidation. In addition, it inhibits the activation of NFkB-mediated signal transductions induced by ROS through antioxidant activity [77]. ROS as well as superoxide and hydroxyl radicals are considered as initiators of free radicals chain reactions of lipid peroxidation. Pomegranate juice, rich flavonoids, and ellagitannins or ellagic acid, have shown an antioxidant activity against ROS-induced AGEs or ALEs formation. According to the report, extracts of Achyrocline satureoides (Lam.) DC. (Compositae) and Ilex paraguariensis A.St.-Hil. (Aquifoliaceae) inhibited AGE-precursor formation as potent as synthetic AGEs inhibitors, including aminoguanidine or carnosine [78]. Thymoquinone a major component of black seed, Nigella sativa L. (Ranunculaceae), has demonstrated inhibitory activity against early and late AGEs compounds formation by scavenging ROS. Compared to aminoguanidine, thymoquinone inhibited $39 \%$ of hemoglobin glycation and $82 \%$ of post Amadori glycation products formation in human serum albumin-glucose system [79].
Moreover quercetin and rutin inhibited glucose autoxidation and glycation of collagen as well [70]. According to the report Sallylcysteine, S-ethylcysteine and $\mathrm{N}$-acetylcysteine isolated from Allium sativum L. (Amaryllidaceae) inhibited AGEs formation and decreased LDL glycation level through their antioxidant properties [50]. N-acetylcysteine contain free sulfhydryl groups (thiol groups) in its structure. Thiol group have a noticeable potential to freely react with electrophilic compounds such as ROS to scavenge them and prevent lipid peroxidation. Moreover it is an important contributor to conservation of the cellular glutathione status $[80,81]$. In a study conducted by Kim et al., puerarin, PG3, and puerol B isolated from root of Pueraria lobata (Willd.) Ohwi (Fabaceae) were identified as major contributors of antiglycation activity by inhibition of ROS [82,83].

In plants under stress, phytochemicals ameliorate oxidative stress through several antioxidant activity mechanisms. Fortunately, such mechanisms are effective to improve oxidative stress in humans as well. Extract of bitter melon, Momordica charantia L. (Cucurbitaceae), improved oxidative stress by lowering triglyceride, cholesterol or plasma glucose levels [84]. Another mechanism to attenuate oxidative stress is the deactivation of the enzymes responsible for ROS generation, such as xanthine oxidase, cyclooxygenase, lipoxygenase, microsomal monooxygenase, and NADH oxidase. Polyphenols such as flavonoids, carotenoids, ascorbic acid, and tocopherols limit substrate for such enzymes via lowering ROS levels by chelating or neutralizing the transition metal ions by donating electron or hydrogen atoms to free radicals such as superoxide, hydroxyl, alkoxyl, and peroxyl [59]. Caffeic and chlorogenic acids, predominant phytochemicals of I. paraguariensis extract, have shown more powerful antiglycation properties than aminoguanidine. They interfere glucose metabolism by free radicals scavenging or chelating of transition metal ions [85].

In vivo studies showed that curcumin not only increased the levels of non-enzymatic antioxidants, e.g., vitamin C, E, and glutathione but also reduced lipid peroxidation products and crosslinking of collagen in diabetic rats [66]. Lin et al. reported that curcumin improved AGEs-induced oxidative stress by activation of glutamate-cysteine ligase and suppression of RAGE gene expression in an in vitro study on hepatic stellate cells [86]. In a comparative study, Kaewnarin et al. displayed that among twenty different plant species, $P$. granatum, Dimocarpus longan Lour. (Sapindaceae) and Mangifera indica L. (Anacardiaceae) showed higher antioxidant and antiglycation activity due to their higher content of phenolic and flavonoid compounds. There was a relationship between the antioxidant and antiglycation activities of those plants [87]. 


\section{Metal chelating activity}

Chelation of transition metal ions such as copper and iron by synthetic or natural compounds is one of the promising mechanisms for the inhibition of AGEs formation in diabetic patients. In hyperglycemia, transition metals in presence of oxygen catalyze autoxidation of glucose or lipid peroxidation. Then as a result Amadori products are generated, which may react with protein to form AGEs. Transition metal ions assist the formation of oxygen free radicals such as hydroxyl radicals during Fenton reaction or lipid peroxidation. For example decomposition of $\mathrm{LOOH}$ by metal ions produces lipid alkoxy as an initiator for free radical chain reaction. Some polyphenols such as flavonoids scavenge lipid alkoxy and suppress lipid peroxidation. Metal chelation occurs through binding of carboxyl or the hydroxyl group of a polyphenol to transition metal ions like iron or copper. In BSA-fructose system, garcinol from Garcinia indica (Thouars) Choisy (Clusiaceae) inhibited protein crosslinking and the formation of fluorescence glycation products by metal ion chelating activity [88]. Wu et al. reported that guava extract inhibited Amadori product formation in a dose dependent manner through chelating activity mechanism [89]. Chlorogenic acids, found in edible parts of some plants such as apple, strawberries, pineapple, blueberries, coffee and sunflower act as anti-AGEs by metal chelating, or modulation of antioxidant enzymes gene expression [85]. Rutin as an antioxidant also possesses a chelating property and decreases the Fenton reaction as a source of free radical formation. However there are significant differences between chelating activities of polyphenols in respect to their molecular structure. For example, flavonoids with catechol moiety on ring B show an antioxidant activity, but to be a chelator as well, the presence of $\mathrm{OH}$ on $\mathrm{C} 3$ is necessary [90]. On the other hand, different transition metal ions exhibit specific binding affinity to the flavonoids depending on their structure. For instance iron has the best binding affinity on ring $\mathrm{C}(\mathrm{C} 3-\mathrm{OH})$, ring $\mathrm{B}$ (catechol group) and ring $\mathrm{A}(\mathrm{C} 5-\mathrm{OH})$ while copper shows the best binding affinity on catechol containing flavonoids [91].

\section{Antilipoxidation properties}

Protein modification is occurred by both carbohydrates and lipids via glycation or lipoxidation, respectively. In brief, lipids or polyunsaturated fatty acids, such as linoleic and linolenic acids, under nonenzymatic peroxidation produce peroxide intermediates. After some metabolic pathways, peroxide intermediates are degraded to RCS such as MAD, GO, or MGO. Later, some of these reactive dicarbonyl compounds depending to undergoing pathway, produce stable adducts or crosslinks known as AGEs or ALEs. Indeed some AGEs or ALEs adducts have the same molecular structure. For example a reaction of glyoxal with lysine residues produces CML, which is considered as an ALE or AGE compound [13].

Plant phenolic compounds such as punicalagin, ellagic acid, anthocyanins, oleanolic acid, ursolic acid, or gallic acid, which can all be found in pomegranate [92] have shown a lipid oxidation inhibitory activity by scavenging free radicals [93]. Phytochemicals such as oleanolic acid and ursolic acid in pomegranate flower extracts have shown antihyperlipidemic activities [92]. Plants with hypoglycemia activity such as T. foenum-graeceum seeds have the potential to ameliorate diabetic complication by decreasing triglyceride, serum cholesterol LDL (but not HDL) and finally AGEs formation [94]. It has been reported that extracts of Toona sinensis (A. Juss.) M. Roem. (Meliaceae). and Graptopetalum paragugayense (N.E.Br.) E.Walther (Crassulaceae) prevented AGEs for- mation originating from LDL [95]. Lizcano et al. showed the antilipidoxidation of prepared extracts of leaves, flower and stem of some Amazonian plants, including Brownea rosa-de-monte Bergius (Fabaceae), Piper glandulosissimum Yunck. (Piperaceae), Piper krukoffii Yunck., Piper putumayoense Trel. \& Yunck., Solanum grandiflorum Ruiz \& Pav. (Solanaceae), and Vismia baccifera (L.) Planch. \& Triana (Hypericaceae). All the extracts, excluding the P. glandulosissimum stem extract, showed anti-lipid peroxidation activities [96].

\section{Trapping of reactive carbonyl species}

Trapping of reactive dicarbonyl compounds such as MGO, GO or 3-deoxyglucosone is an important approach to inhibit AGEs formation. Epicatechins and theaflavins found in green and black tea, respectively, lowered the amount of MGO to the physiological levels [97]. Active components of guava [Psidium guajava L. (Myrtaceae)] leaves, including gallic acid, catechin and quercetin [89] or procyanidins isolated from various species of berries (blueberries, blackberries, strawberries, raspberries, cranberries) prevented AGEs formation by trapping $\alpha$-dicarbonyl compounds or inhibiting Amadori product formation [98]. Similarly, 2,3,5,4' tetrahydroxystilbene 2-O-beta-D-glucoside (THSG), the predominant active compound of P. multiflorum prevented AGEs formation by trapping MGO. THSG was more potent than bioactive dietary stilbenes including resveratrol and its methylated derivative, pterostilbene. Main active sites for MGO trapping were positions 4 and 6 of the A ring in their structures [99]. Metabolites of rutin, especially those containing vicinyl dihydroxyl groups in the B-ring inhibited formation of AGEs, i.e., pentosidine or CML by trapping of reactive dicarbonyl and ROS. Quercetin and rutin, flavonoids in tomato paste, prevented formation of fructosamines by trapping $\alpha$-dicarbonyl compounds in early stage of Maillard reaction [100]. In an experiment gallic acid, p-coumaric acid, and epicatechin, bioactive compounds of Cyperus rotundus L. (Cyperaceae), reduced protein carbonyl, thiol oxidation and fluorescence AGEs formation [5]. Cell culture experiment conducted by Ramful et al., revealed that the physiological concentration of flavedo (exocarp) extract of orange skin extracts of tangor Elendale (Citrus reticulata $\times$ Citrus sinensis) and tangelo Minneola (C. reticulata $\times$ Citrus paradisis), decreased AGEs formation by lowering the level of carbonyl compounds in H2O2-treated adipocytes [101].

\section{Regulation of gene expression}

The effects of phytochemicals on gene expression have been investigated in relation to glucose transporter, insulin secretion or lipid metabolisms. The activity of GLUT-4, as a major glucose transporter in muscles, is regulated by insulin secretion. In an experiment with diabetic rats, resveratrol increased the expression of GLUT-4 in muscles [59]. Likewise other phytochemicals such as anthocyanins and anthocyanidins have demonstrated an antiglycation activity through upregulation of PPAR gamma expression or other genes engaging in glucose or lipid metabolism [102]. In an animal study, puerarin isolated from P. lobata decreased CMLinduced inflammation by induction of the HO-1(heme oxygenase-1) enzyme expression. HO-1 converts heme to biliverdin which is reduced enzymatically to bilirubin as a powerful antioxidant. HO-1 also increased NF-E2 related factor-2 (Nrf-2) translocation which in turn up-regulate HO-1 expression [103]. An in vitro study revealed that flavonoids including catechin, EGCG, luteolin, and rutin more or less inhibited CML formation. However flavones (luteolin) showed the utmost inhibitory activity on ex- 
pression of inflammatory genes such as TNF- $\alpha$, interleukin- $1 \mathrm{~b}$, and cyclooxygenase- 2 in hyperglycemia condition. The plausible explanation for their antiglycation abilities is a downregulation of RAGE-mRNA expression, which is an integral part of RAGE formation [20].

PPAR gamma, a member of the nuclear receptor proteins, has a pivotal role in carbohydrates and lipids metabolisms, via downregulation of RAGE expression or upregulation of paraoxonase-1 expression, a HDL-associated lipolactonase with antioxidative properties [104]. PPAR alpha plays a role to improve inflammation by inhibition of expression of related genes. Polyphenols have shown significant effects on activation of PPAR $\gamma$ or PPAR $\alpha$ in the cells. In an in vitro study, gallic acid as a predominant compound in pomegranate flower extract, increased the cardiac PPAR-gamma mRNA expression along with enhancing the sensitivity to insulin receptor [105]. Therefore it can be concluded that pomegranate flower extract is capable to inhibit or decrease AGEs formation through these mechanisms. On the other hand, Lin et al. showed in an experiment that curcumin, an active compound of turmeric, stimulated the gene expression of AGE-receptor- 1 in hepatic stellate cells. This receptor acts as the responsible factor for the detoxification and clearance of AGEs. Moreover, it prevented the activity of extracellular signal-regulated kinase along with the stimulation of gene expression and activity of PPAR-gamma [106]. Phytochemicals such as auraptene from Citrus fruit or bixins isolated from pericarp of Bixa orellana L. (Bixaceae) seeds have demonstrated a hypoglycemic effect through increasing the glucose uptake in a way of activation of PPAR [107].

\section{Conclusion}

$\nabla$

Critical levels of AGEs in cells contribute to the induction of different complications, including micro and macroangiopathy disorders, especially in hyperglycemia condition. These heterogeneous compounds or even their precursors exert their harmful effects by protein dysfunction via binding to an amino group of proteins, crosslinking of proteins or increasing oxidative stress. Phytochemicals with various structures possess antioxidant or chelating activities and therefore are capable of inhibiting AGEs formation. Polyphenols show antiglycation activity using various approaches such as neutralization of ROS, trapping dicarbonyl compounds, activation of enzymatic antioxidants in the body, breaking the cross-linking of proteins. Some natural compounds possess a stronger antiglycation ability than synthetic compounds. These compounds may be introduced as promising prototype drugs, which may eventually evolve into drugs for the remedy of diabetes complications in the future. If we hope to develop drugs from naturally occurring compounds, it is necessary to know the mechanism of action by which the phytochemical inhibits AGEs formation. AGEs are produced during several reactions, thus for an effective inhibition with a high reproducibility of results it is crucial to know the reaction process and how the compounds affect the AGEs formation. With respect to the different roles of phytochemicals in hyperglycemia, phytochemical therapy is perhaps a window to the remedy of diabetic complications.

\section{Acknowledgements}

$\nabla$

For this manuscript the authors thank Universiti Teknologi Malaysia RGU vot. 03H95, Ministry of Agriculture (NRGS vot.4H016), Institute of Bioproducts Developments (IBD) UTM and Shahed University of Iran for their support and arranging to bring together authors to prepare the multidisciplinary manuscript.

\section{Conflict of Interest}

$\nabla$

The authors declare no conflict of interest.

\section{References}

1 Chang TKH. Activation of pregnane X receptor (PXR) and constitutive androstane receptor (CAR) by herbal medicines. AAPS J 2009; 11: 590-601

2 Masaki H, Okano Y, Sakurai $H$. Generation of active oxygen species from advanced glycation end-products (AGEs) during ultraviolet light A (UVA) irradiation and a possible mechanism for cell damaging. Biochim Biophys Acta 1999; 1428: 45-56

3 Peng X, Zheng Z, Cheng K, Shan F, Ren G, Chen F, Wang M. Inhibitory effect of mung bean extract and its constituents vitexin and isovitexin on the formation of advanced gglycation end products. Food Chem 2008; 106: 475-481

4 Jagt DLV, Hunsaker LA. Methylglyoxal metabolism and diabetic complications: roles of aldose reductase, glyoxalase-I, betaine aldehyde dehydrogenase and 2-oxoaldehyde dehydrogenase. Chem Biol Interact 2003; 143-144: 341-354

5 Ardestani A, Yazdanparast R. Cyperus rotundus suppresses AGE formation and protein oxidation in a model of fructose-mediated protein glycoxidation. Int J Biol Macromol 2007; 41: 572-578

6 Vasan S, Foiles P, Founds $H$. Therapeutic potential of breakers of advanced glycation end product-protein crosslinks. Arch Biochem Biophys 2003; 419: 89-96

7 Zhang $Q$ Ames JM, Smith RD, Baynes JW, Metz TO. A perspective on the Maillard reaction and the analysis of protein glycation by mass spectrometry: probing the pathogenesis of chronic disease. J Proteome Res 2009; 8: 754-769

8 Elosta A, Ghous T, Ahmed N. Natural products as anti-glycation agents: possible therapeutic potential for diabetic complications. Curr Diabetes Rev 2012; 8: 92-108

9 Peyroux J, Sternberg M. Advanced glycation end products(AGEs): pharmacological inhibition in diabetes. Pathol Biol 2006; 54: 405-419

10 Singh VP, Bali A, Singh N, Jaggi AS. Advanced glycation end products and diabetic complications. Korean J Physiol Pharmacol 2014; 18: 1-14

11 Vlassara H. The AGE-receptor in the pathogenesis of diabetic complications. Diabetes Metab Res Rev 2001; 17: 436-443

12 Peppa $M$, Vlassara $H$. Advanced glycation end products and diabetic complications: a general overview. Hormones 2005; 4: 28-37

13 Vistoli G, De Maddis D, Cipak A, Zarkovic N, Carini M, Aldini G. Advanced glycoxidation and lipoxidation end products (AGEs and ALEs): an overview of their mechanisms of formation. Free Radic Res 2013; 47 (Suppl. 1): 3-27

14 Ho SC, Chang PW. Inhibitory effects of several spices on inflammation caused by advanced glycation endproducts. Am J Plant Sci 2012; 3: 995-1002

15 Bopp C, Bierhaus A, Hofer S, Bouchon A, Nawroth PP, Martin E, Weigand $M A$. Bench-to-bedside review: The inflammation-perpetuating patternrecognition receptor RAGE as a therapeutic target in sepsis. Crit Care 2008; 12: 1-8

16 Hsu D, Zimmer V. Canadian diabetes association national nutrition committee technical review: advanced glycation end-products in diabetes management. Can J Diabetes 2010; 34: 136-140

17 Mathys KC, Ponnampalam SN, Padival S, Nagaraja RH. Semicarbazidesensitive amine oxidase in aortic smooth muscle cells mediates synthesis of a methylglyoxal-AGE: Implications for vascular complications in diabetes. Biochem Biophys Res Commun 2002; 297: 863-869

18 Yuan Y, Zhao L, Chen Y, Moorhead JF, Varghese Z, Powis SH, Minogue S, Sun Z, Ruan XZ. Advanced glycation end products (AGEs) increase human mesangial foam cell formation by increasing Golgi SCAP glycosylation in vitro. Am J Physiol Renal Physiol 2011; 301: F236-F243 
19 Hegab Z, Gibbons S, Neyses L, Mamas MA. Role of advanced glycation end products in cardiovascular disease. World J Cardiol 2012; 4: 90102

$20 \mathrm{Wu} C H, W u C F$, Huang HW, Jao YC, Yen GC. Naturally occurring flavonoids attenuate high glucose-induced expression of proinflammatory cytokines in human monocytic THP-1 cells. Mol Nutr Food Res 2009; 53: 984-995

21 Iborra RT, Machado-Lima A, Castilho G, Nunes VS, Abdalla DS, Nakandakare ER, Passarelli $M$. Advanced glycation in macrophages induces intracellular accumulation of 7-ketocholesterol and total sterols by decreasing the expression of ABCA-1 and ABCG-1. Lipids Health Dis 2011; 10: 172

22 Basta G, Lazzerini G, Massaro M, Simoncini T, Tanganelli P, Fu C, Kislinger $T$, Stern D, Schmidt A, De Caterina R. Advanced glycation end products activate endothelium through signal-transduction receptor RAGE: a mechanism for amplification of inflammatory responses. Circulation 2002; 105: 816-822

23 Magalhaes PM, Appell HJ, Duarte JA. Involvement of advanced glycation end products in the pathogenesis of diabetic complications: the protective role of regular physical activity. Eur Rev Aging Phys Act 2008; 5: 17-29

24 Barlovic DP, Soro-Paavonen A, Jandeleit-Dahm KAM. RAGE biology, atherosclerosis and diabetes. Clin Sci 2011; 121: 43-55

25 Milne R, Brownstein S. Advanced glycation end products and diabetic retinopathy. Amino Acids 2013; 44: 1397-1407

26 Higashimoto Y, Matsui T, Nishino Y, Taira J, Inoue H, Takeuchi M, Yamagishi S. Blockage by phosphorothioate aptamers of advanced glycation end products-induced damage in cultured pericytes and endothelial cells. Microvasc Res 2013; 90: 64-70

27 Tanaka N, Yonekura H, Yamagishi S, Fjimori H, Yamamoto Y, Yamamoto $H$. The receptor for advanced glycation endproducts is induced by the glycation products themselves and tumour necrosis factor-a through nuclear factor-kB, and by $17 \mathrm{~b}$-estradiol through Sp-1 in human vascular endothelial cells. J Biol Chem 2000; 275: 25781-25790

28 Yamagishi S, Nakamura K, Matsui T. Advanced glycation end products (AGEs) and their receptor (RAGE) system in diabetic retinopathy. Curr Drug Discov Technol 2006; 3: 83-88

29 Yamagishi S. Role of advanced glycation end products (AGEs) and receptor for AGEs (RAGE) in vascular damage in diabetes. Exp Gerontol 2011; 46: 217-224

30 Ahmed $N$. Advanced glycation endproducts-role in pathology of diabetic complications. Diabetes Res Clin Pract 2005; 67: 3-21

31 Tsilibary EC. Microvascular basement membranes in diabetes mellitus. J Pathol 2003; 200: 537-546

32 Vlassara H, Striker LJ, Teichberg S, Fuh H, Li YM, Steffes M. Advanced glycosylation endproducts induce glomerular sclerosis and albuminuria in normal rats. Proc Natl Acad Sci U S A 1994; 91: 11704-11708

33 Yamamoto Y, Kato I, Doi T, Yonekura H, Ohashi S, Takeuchi M, Watanabe T, Yamagishi S, Sakurai S, Takasawa S, Okamoto H, Yamamoto H. Development and prevention of advanced diabetic nephropathy in RAGEoverexpressing mice. J Clin Invest 2001; 108: 261-268

34 Tan K, Shiu SW, Chow WS, Leng L, Bucala R, Betteridge DJ. Association between serum levels of soluble receptor for advanced glycation end products and circulating advanced glycation end products in type 2 diabetes. Diabetologia 2006; 49: 2756-2762

35 Peng $X$, Ma J, Chen $F$, Wang $M$. Naturally occurring inhibitors against the formation of advanced glycation end-products. Food Funct 2011; 2: 289-301

36 Jack $M$, Wright $D$. Role of advanced glycation endproducts and glyoxalase I in diabetic peripheral sensory neuropathy. Transl Res 2012; 159: 355-365

37 Karmakar PS, Goswami RP. Advanced glycation end products (AGEs): it's role in the pathogenesis of diabetic complications. Med Update 2012; 22: 277-282

38 Goova MT, Li J, Kislinger T, Qu W, Bucciarelli LG, Nowygrod S, Wolf BM, Caliste X, Yan SF, Stem DM, Schmidt AM. Blockade of receptors for advanced glycation endproducts restores effective wound healing in diabetic mice. Am J Pathol 2001; 159: 513-525

39 Gould A, Naidoo C, Kruger D, Candy G. The role of advanced glycation end products in the hyperinflammatory response of diabetic wounds. Wound Heal S Afr 2011; 4: 25-28

40 Zhu P, Ren M, Yang C, Hu Y, Ran J, Yan L. Involvement of RAGE, MAPK and NF-jB pathways in AGEs-induced MMP-9 activation in HaCaT keratinocytes. Exp Dermatol 2011; 21: 123-129
41 Owen WF Jr, Hou FF, Stuart RO, Kay J, Boyce J, Chertow GM, Schmidt AM. $\beta_{2}$-Microglobulin modified with advanced glycation end products modulates collagen synthesis by human fibroblasts. Kidney Int 1998; 53: $1365-1373$

42 Peppa M, Brem H, Ehrlich P, Zhang JG, Cai W, Li Z, Croitoru A, Thung S, Vlassara $H$. Adverse effects of dietary glycotoxins on wound healing in genetically diabetic mice. Diabetes 2003; 52: 2805-2813

43 Xie Y, Chen X. Structures required of polyphenols for inhibiting advanced glycation end products formation. Curr Drug Metab 2013; 14: 414-431

44 Doughari JH, Human IS, Bennade S, Ndakidemi PA. Phytochemicals as chemotherapeutic agents and antioxidants: Possible solution to the control of antibiotic resistant verocytotoxin producing bacteria. J Med Plants Res 2009; 3: 839-848

45 Peng X, Cheng K, Ma J, Chen B, Ho C, Lo C, Chen F, Wang M. Cinnamon bark proanthocyanidins as reactive carbonyl scavengers to prevent the formation of advanced glycation endproducts. J Agric Food Chem 2008; 56: 1907-1911

46 Michalak A. Phenolic compounds and their antioxidant activity in plants growing under heavy metal stress. Pol J Environ Stud 2006; 15: 523-530

47 Mizutani K, Ikeda K, Yamori K. Resveratrol inhibits AGEs-induced proliferation and collagen synthesis activity in vascular smooth muscle cells from stroke-prone spontaneously hypertensive rats. Biochem Biophys Res Commun 2000; 274: 61-67

48 McIntyre K, Harris C, Saleem A, Beaulieu L, Ta C, Haddad P, Arnason J. Seasonal phytochemical variation of anti-glycation principles in lowbush blueberry (Vaccinium angustifolium). Planta Med 2009; 75: 286292

49 Tsuji-Naito K, Saeki H, Hamano M. Inhibitory effects of chrysanthemum species extracts on formation of advanced glycation end products. Food Chem 2009; 116: 854-859

50 Ramkissoon JS, Mahomoodally FM, Ahmed N, Subratty HA. Natural inhibitors of advanced glycation end-products. Nutr Food Sci 2012; 42: 397-404

51 Chompoo J, Upadhyay A, Kishimoto W, Makise T, Tawata S. Advanced glycation end products inhibitors from Alpinia zerumbet rhizomes. Food Chem 2011; 129: 709-715

52 Ferchichi L, Derbre S, Mahmood K, Toure K, Guilet D, Litaudon M, Awang $K$, Hadi AH, Le Ray AM, Richomme P. Bioguided fractionation and isolation of natural inhibitors of advanced glycation end-products (AGEs) from Calophyllum flavoramulum. Phytochemistry 2012; 78: 98-106

53 Lunceford N, Gugliucci A. Ilex paraguariensis extracts inhibit AGE formation more eefficiently than green tea. Fitoterapia 2005; 76: 419427

54 Sang S, Shao X, Bai N, Lo CY, Yang CS, Ho CT. Tea polyphenol (-)-epigallocatechin-3-gallate: a new trapping agent of reactive dicarbonyl species. Chem Res Toxicol 2007; 20: 1862-1870

55 Obanda DN, Hernandez A, Ribnicky D, Yu Y, Zhang XH, Wang ZQ Cefalu WT. Bioactives of Artemisia dracunculus L. mitigate the role of ceramides in attenuating insulin signaling in rat skeletal muscle cells. Diabetes 2012: 61: 597-605

56 Taher M, Abdul majid FA, Sarmidi MR. A proanthocyanidin from cinnamomum zeylanicum stimulates phosphorylation of insulin receptor in 3t3-L1 adipocytes. J Teknol 2006; 44: 53-68

57 Zhao HL, Sui Y, Qiao CF, Yip KY, Leung RKK, Tsui SKW, Lee HM, Wong HKT, Zhu X, Siu JJ, He L, Guan J, Liu LZ, Xu HX, Tong PCY, Chan JCN. Sustained antidiabetic effects of a berberine-containing chinese herbal Medicine through regulation of hepatic gene expression. Diabetes 2012; 61: 933-943

58 Peng CH, Chyau CC, Chan KC, Chan TH, Wang CJ, Huang CN. Hibiscus sabdariffa polyphenolic extract inhibits hyperglycemia, hyperlipidemia, and glycation-oxidative stress while improving insulin resistance. J Agric Food Chem 2011; 59: 9901-9909

59 Dembinska-Kiec A, Mykkänen O, Kiec-Wilk B, Mykkänen H. Antioxidant phytochemicals against type 2 diabetes. Br J Nutr 2008; 99: ES109ES117

60 Wang H, Song L, Feng S, Liu Y, Zuo G, Lai F, He G, Chen M, Huang D. Characterization of proanthocyanidins in stems of Polygonum multiflorum Thunb as strong starch hydrolase inhibitors. Molecules 2013; 18: 2255-2265

61 Gurav S, Gulkari V, Duragkar N, Patil A. Systemic review: Pharmacognosy, phytochemistry, pharmacology and clinical applications of Gymnema sylvestre R Br. Pharmacogn Rev 2007; 1: 337-343 
62 Eshrat H, Hussain MA. Hyperglycemic, hypolepidemic and antioxidant properties of combination of cucurmin from Curcuma longa Lin. and partially purified product from Abroma augusta Lin. in Streptozotocin induced diabetes. Indian J Clin Biochem 2002; 17: 33-43

63 Seo K, Choi M, Jung U, Kim H, Yeo J, Jeon S, Lee M. Effect of curcumin supplementation on blood glucose, plasma insulin, and glucose homeostasis related enzyme activities in diabetic $\mathrm{db} / \mathrm{db}$ mice. Mol Nutr Food Res 2008; 52: 995-1004

64 Tang $Y$, Chen A. Curcumin prevents leptin raising glucose levels in hepatic stellate cells by blocking translocation of glucose transporter-4 and increasing glucokinase. Br J Pharmacol 2010; 16: 1137-1149

65 Xiao J, Ni X, Kai G, Chen X. A review on structure-activity relationship of dietary polyphenols inhibiting alpha-amylase. Crit Rev Food Sci Nutr 2013; 53: 497-506

66 Sajithlal GB, Chithra P, Chandrakasan G. Effect of Curcumin on the advanced glycation and cross-linking of collagen in diabetic rats. Biochem Pharmacol 1998; 56: 1607-1614

67 Kavishankar GB, Lakshmidevi N, Mahadeva Murthy S, Prakash HS, Niranjana SR. Diabetes and medicinal plants-a review. Int J Pharm Biomed Sci 2011; 2: 65-80

68 Hallam KM, Li Q Ananthakrishnan R, Kalea A, Zou YS, Vedantham S, Schmidt AM, Yan SF, Ramasamy R. Aldose reductase and AGE-RAGE pathways: central roles in the pathogenesis of vascular dysfunction in aging rats. Aging Cell 2010; 9: 776-784

69 Lee EH, Song DG, Lee JY, Pan CH, Um BH, Jung SH. Inhibitory effect of the compounds isolated from Rhus verniciflua on aldose reductase and advanced glycation endproducts. Biol Pharm Bull 2008; 31: 16261630

70 Cervantes-Laurean D, Schramm DD, Jacobson EL, Halaweish I, Bruckner $G G$, Boissonneault GA. Inhibition of advanced glycation end product formation on collagen by rutin and its metabolites. J Nutr Biochem 2006; 17: 531-540

71 Jung SH, Lee JM, Lee HJ, Kim CY, Lee EH, Um BH. Aldose reductase and advanced glycation endproducts inhibitory effect of Phyllostachys nigra. Biol Pharm Bull 2007; 30: 1569-1572

72 Wirasathien L, Pengsuparp T, Suttisri R, Ueda H, Moriyasu M, Kawanishi $K$. Inhibitors of aldose reductase and advanced glycation endproducts formation from the leaves of Stelechocarpus cauliflorus R.E. Fr. Phytomedicine 2007; 14: 546-550

73 Fuente JA, Manzanaro S. Aldose reductase inhibitors from natural sources. Nat Prod Rep 2003; 20: 243-251

74 Baba SP, Hellmann J, Srivastava S, Bhatnagar A. Aldose reductase (AKR1B3) regulates the accumulation of advanced glycosylation end products (AGEs) and the expression of AGE receptor (RAGE). Chem Biol Interact 2011; 191: 357-363

75 Nagai R, Unno Y, Hayashi MC, Masuda S, Hayase F, Kinae N, Horiuchi S. Peroxynitrite induces formation of $n$-(carboxymethyl)lysine by the cleavage of Amadori product and generation of glucosone and glyoxal from glucose novel pathways for protein modification by peroxynitrite. Diabetes 2002; 51: 2833-2839

76 Nagai R, Ikeda K, Higashi T, Sano H, Jinnouchi Y, Araki T, Horiuchi S. Hydroxyl radical mediates $\mathrm{N}$ epsilon-(carboxymethyl)lysine formation from Amadori product. Biochem Biophys Res Commun 1997; 234 : $167-172$

77 Celik I, Temur A, Isik I. Hepatoprotective role and antioxidant capacity of pomegranate (Punica granatum) flowers infusion against trichloroacetic acid-exposed in rats. Food Chem Toxicol 2009; 47: 145-149

78 Gugliucci A, Menini T. The botanical extracts of Achyrocline satureoides and Ilex paraguariensis prevent methylglyoxal-induced inhibition of plasminogen and antithrombin. Life Sci 2002; 72: 279-292

79 Losso JN, Bawadi HA, Chintalapati M. Inhibition of the formation of advanced glycation end products by thymoquinone. Food Chem 2011; 128: 55-61

80 Kamalakkannan N, Rukkumani R, Aruna K, Varma PS, Viswanathan $P$, Menon VP. Protective effect of n-acetyl cysteine in carbon tetrachloride-induced hepatotoxicity in rats. Iranian J Pharmacol Ther 2005; 4 : 118-123

81 Bavarsad Shahripour $R$, Harrigan MR, Alexandrov AV. N-acetylcysteine (NAC) in neurological disorders: mechanisms of action and therapeutic opportunities. Brain Behav 2014; 4: 108-122

82 Kim J, Kim KM, Kim CS, Sohn E, Lee YM, Jo K, Kim JS. Puerarin inhibits the retinal pericyte apoptosis induced by advanced glycation end products in vitro and in vivo by inhibiting NADPH oxidase-related oxidative stress. Free Radic Biol Med 2012; 15: 357-365
83 Kim JM, Lee YM, Lee GY, Jang DS, Bae KH, Kim JS. Constituents of the roots of Pueraria lobata inhibit formation of advanced glycation end products (AGEs). Arch Pharm Res 2006; 29: 821-825

84 Ahmed I, Lakhani MS, Gillett M, John A, Raza H. Hypotriglyceridemic and hypocholesterolemic effects of anti-diabetic Momordica charantia (karela) fruit extract in streptozotocin-induced diabetic rats. Diabetes Res Clin Pract 2001; 51: 155-161

85 Gugliucci A, Bastos DHM, Schulze J, Souza MF. Caffeic and chlorogenic acids in Ilex paraguariensis extracts are the main inhibitors of AGE generation by methylglyoxal in model proteins. Fitoterapia 2009; 80 : 339-344

86 Lin J, Tang Y, Kang Q Feng Y, Chen A. Curcumin inhibits gene expression of receptor for advanced glycation endproducts (RAGE) in hepatic stellate cells in vitro by elevating PPARg activity and attenuating oxidative stress. Br J Pharmacol 2012; 166: 2212-2227

87 Kaewnarin K, Niamsup H, Shank L, Rakariyatham N. Antioxidant and antiglycation activities of some edible and medicinal plants. Chiang Mai J Sci 2014; 41: 105-116

88 Yamaguchi F, Ariga T, Yoshimura Y, Nakazawa $H$. Antioxidative and anti-glycation activity of garcinol from Garcinia indica fruit rind. J Agric Food Chem 2000; 48: 180-185

89 Wu J, Hsieh C, Wang $H$, Chen $H$. Inhibitory effects of guava (Psidium guajava L.) leaf extracts and its active compounds on the glycation process of protein. Food Chem 2009; 113: 78-84

90 van Acker SA, van den Berg DJ, Tromp MN, Griffioen DH, van Bennekom WP, van der Vijgh WJ, Bast A. Structural aspects of antioxidant activity of flavonoids. Free Radic Biol Med 1996; 20: 331-342

91 Kaurinovic B, Popovic M. Liposomes as a tool to study lipid peroxidation. In: Catala A, editor. Lipid peroxidation. Rijeka: InTech; 2012: $155-180$

92 Al-Muammar MN, Khan K. Obesity: The preventive role of the pomegranate (Punica granatum). Nutrition 2012; 28: 595-604

93 Aviram M, Dornfeld L, Rosenblat M, Volkova N, Kaplan M, Coleman R, Hayek T, Presser D, Fuhrman B. Pomegranate juice consumption reduces oxidative stress, atherogenic modifications to LDL, and platelet aggregation: studies in humans and in atherosclerotic apolipoprotein E-deficient mice. Am J Clin Nutr 2000; 71: 1062-1076

94 Abdel-Barry JA, Abdel-Hassan IA, Al-Hakiem MH. Hypoglycaemic and antihyperglycaemic effects of Trigonella foenum-graecum leaf in normal and alloxan induced diabetic rats. J Ethnopharmacol 1997; 58: 149-155

95 Hsieh C, Lin Y, Ko W, Peng C, Huang C, Peng $R$. Inhibitory effect of some selected nutraceutic herbs on LDL glycation induced by glucose and glyoxal. J Ethnopharmacol 2005; 102: 357-363

96 Lizcano LJ, Viloria-Bernal M, Vicente F, Berrueta LA, Gallo B, MartinezCanamero M, Ruiz-Larrea MB, Ruiz-Sanz JI. Lipid oxidation inhibitory effects and phenolic composition of aqueous extracts from medicinal plants of colombian amazonia. Int J Mol Sci 2012; 13: 5454-5467

97 Lo CY, Li L, Tan D, Pan M, Sang S, Ho C. Trapping reactions of reactive carbonyl species with tea polyphenols in simulated physiological conditions. Mol Nutr Food Res 2006; 50: 1118-1128

98 Wang W, Yagiz Y, Buran TJ, Nunes CDN, Gu L. Phytochemicals from berries and grapes inhibited the formation of advanced glycation endproducts by scavenging reactive carbonyls. Food Res Int 2011; 44: 2666-2673

99 Lv L, Shao X, Wang L, Huang D, Ho C, Sang S. Stilbene glucoside from Polygonum multiflorum Thunb.: a novel natural inhibitor of advanced glycation end product formation by trapping of methylglyoxal. J Agric Food Chem 2010; 58: 2239-2245

100 Kiho T, Usui S, Hirano K, Aizawa K, Inakuma T. Tomato paste fraction inhibiting the formation of advanced glycation end-products. Biosci Biotechnol Biochem 2004; 68: 200-205

101 Ramful D, Tarnus E, Rondeau P, Da Silva CR, Bahorun T, Bourdon E. Citrus fruit extracts reduce advanced glycation end products (AGEs)- and $\mathrm{H}_{2} \mathrm{O}_{2}$-induced oxidative stress in human adipocytes. J Agric Food Chem 2010; 58: 11119-11129

102 Martineau LC, Couture A, Spoor D, Benhaddou-Andaloussi A, Harris C, Meddah M, Leduc C, Burt A, Vuong T, Le PM, Prentki M, Bennett SA, Arnason GT, Haddad PS. Anti-diabetic properties of the Canadian lowbush blueberry Vaccinium angustifolium Ait. Phytomedicine 2006; 13: 612-623

103 Kim KM, Jung DH, Jang DS, Kim YS, Kim JM, Kim HN, Surh YJ, Kim JS. Puerarin suppresses AGEs-induced inflammation in mouse mesangial cells: A possible pathway through the induction of heme oxygenase1 expression. Toxicol Appl Pharmacol 2010; 244: 106-113 
104 Khateeb J, Gantman A, Kreitenberg AJ, Aviram M, Fuhrman B. Paraoxonase 1 (PON1) expression in hepatocytes is upregulated by pomegranate polyphenols: A role for PPAR- pathway. Atherosclerosis 2010; 208: 119-125

105 Huang THW, Peng G, Kota BP, Li GQ Yamahara J, Roufogalis BD, Li Y. Anti-diabetic action of Punica granatum flower extract: Activation of PPAR-g and identification of an active component. Toxicol Appl Pharmacol 2005; 207: 160-169
106 Lin J, Tang $Y$, Kang $Q$ Chen A. Curcumin eliminates the inhibitory effect of advanced glycation end-products (AGEs) on gene expression of AGE receptor-1 in hepatic stellate cells in vitro. Lab Invest 2012; 92: 827-841

107 Goto T, Takahashi N, Hirai S, Kawada T. Various terpenoids derived from herbal and dietary plants function as PPAR modulators and regulate carbohydrate and lipid metabolism. PPAR Res 2010; 2010: 483958 